Інноватика у вихованні. Випуск 12. 2020.

УДК 377:[811.111'243:005.336.2]

DOI: $\underline{10.35619 / \text { iiu.v1i12.316 }}$

Кощук Вікторія викладач англійської мови, викладач вищої категорії Відокремленого структурного підрозділу «Рівненський автотранспортний фаховий коледж Національного університету водного господарства та природокористування», м. Рівне, Україна ORCID: 0000-0003-1689-7388 e-mail:viktoriabelka74@gmail.com

\title{
ФОРМУВАННЯ ІНШОМОВНОЇ ПРОФЕСІЙНОЇ КОМУНІКАТИВНОЇ КОМПЕТЕНЦІЇ У СТУДЕНТІВ АВТОТРАНСПОРТНОГО ФАХОВОГО КОЛЕДЖУ У ПРОЦЕСІ ВИВЧЕННЯ АНГЛІЙСЬКОЇ МОВИ
}

\begin{abstract}
Анотація. У статті висвітлено практичний аспект реалізації проблеми формування іншомовної професійної комунікативної компетенції у студентів автотранспортного фахового коледжу у процесі вивчення англійської мови 3 досвіду роботи викладача вищої категорії Кощук В. М.

3'ясовано, що комунікативна компетентність передбачає уміння співрозмовників співвідносити мовленнєве висловлювання з цілями і ситуацією спілкування, розуміння взаємостосунків між тими, хто спілкується, а також уміння правильно організувати мовленнєве спілкування з урахуванням культури спілкування як найважливішого каналу трансляції культури нового покоління. Наведено приклади формування іншомовної професійної комунікативної компетенції у студентів автотранспортного фахового коледжу засобами навчальних дисциплін «Англійська мова», «Англійська мова за професійним спрямуванням», «Англійська мова (спецкурс)», що передбачають роботу 3 інформаційними ресурсами, розвиток мовлення на основі мовленнєвих ситуацій, дискусійних та рольових ігор, драматизації, роботи у режимі студент - студент тощо.

Розкрито зміст позааудиторної діяльності з англійської мови у контексті формування іншомовної професійної комунікативної компетенції, що передбачає удосконалення умінь і навичок професійного мовлення відповідно до рівня В1, і грунтується на роботі гуртка «Think English».

Ключові слова: іншомовна професійна комунікативна компетенція, професійно-комунікативні уміння, навички усного та писемного мовлення, позааудиторна робота, гурткова робота.

Постановка проблеми. Оновлення змісту вітчизняної освіти пов'язане 3 iii реформуванням та передбачає іiі уніфікацію 3 сучасними європейськими вимогами та зі світовими стандартами. Приєднання України до Болонського процесу передбачає формування єдиного європейського ринку висококваліфікованої праці, профілізацію української освіти, спрямованої на реалізацію державного освітнього стандарту з урахуванням профілю закладу вищої освіти, а також модернізацію української освіти загалом і підвищення статусу навчальної дисципліни «Іноземна мова» зокрема.
\end{abstract}

(C) Кощук B., 2020 
Необхідність якісної професійної підготовки майбутнього фахівця передбачено як в європейських нормативних документах, зокрема, у Маніфесті Ради Свропи «На шляху до Свропи знань» (1997р.), Доповіді Ради Міністрів на Раді Свропи «Формування майбутніх цілей систем освіти і підготовки» (2001), у «Загальноєвропейські рекомендації з мовної освіти: вивчення, викладання, оцінювання» (Страсбург, 2002 р.), у Програмі «Освіта і підготовка 2010» (2004) та «План дій щодо створення єдиного європейського індикатора провідних компетентностей», так і у вітчизняних, як-от: Закони України «Про професійний розвиток працівників» (2012р.), «Про вищу освіту» (2014р.), Національна стратегія розвитку освіти в Україні на період до 2021 року (2013 р.) та ін. Серед низки завдань, визначених цими документами, увага акцентується на підвищенні рівня якості мовної освіти, зокрема англійської як мови міжнародного спілкування.

Все це зумовлює необхідність перегляду вимог до професійної підготовки майбутніх фахівців, оскільки вони пов'язані насамперед із спрямуванням освітньо-виховної діяльності на вироблення у студентів необхідних іншомовних компетенцій, що у майбутньому дадуть можливість випускникам закладу вищої освіти комфортно почуватися в сучасному світовому мультинаціональному просторі.

Аналіз останніх досліджень 3 проблеми. Проблема змісту та структури професійної підготовки фахівців автотранспортних спеціальностей висвітлюються у цілій низці наукових досліджень, зокрема: особливості розвитку і функціонування іноземної мови у контексті сучасних підходів до ії викладання у закладах вищої освіти дослідили Н. Борисова, Г. Гринюк, О. Кузнецова, С. Ніколаєва; особливостям комунікативно-орієнтованого навчання іноземних мов присвятили свої роботи М. Бондар, Г. Пасюк; сучасні технології професійної підготовки фахівців технічних закладів освіти висвітлено в наукових працях В. Адольфа, С. Картюха, В. Козлюка, Т. Степанюк; проблема формування та розвитку різних видів мовленнєвої діяльності у процесі вивчення іноземної мови проаналізована у дослідженнях Л. Мисюк, Н. Данилюк, Н. Клюйко, В. Куніциної, С. Ніколаєвої, Т. Ціпан та ін.

Мета статті - висвітлити практичний аспект реалізації проблеми формування іншомовної професійної комунікативної компетенції у студентів автотранспортного фахового коледжу у процесі вивчення англійської мови (з досвіду роботи викладача вищої категорії Кощук В. М.)

Виклад основного матеріалу дослідження. Сучасні загальносвітові тенденції, серед яких - перехід до інформаційного постіндустріального суспільства і суттєве поширення масштабів міжкультурної взаємодії, поява та поширення глобальних проблем, які можливо вирішити лише шляхом міжнародної співпраці та професійної комунікації, потребує підготовки фахівця 3 сучасним полікультурним мисленням та вільним володінням іноземними мовами. Така підготовка здійснюється як в мовних, так і немовних закладах вищої освіти. Немовний заклад вищої освіти - це заклад, в якому підготовка спеціалістів не оріснтована на першочергове вивчення іноземної мови. У нашому випадку таким закладом виступає Відокремлений структурний підрозділ «Рівненський автотранспортний фаховий коледж Національного університету водного господарства та природокористування» (ВСП РАТФК НУВГП), який здійснюе підготовку фахівців за спеціальностями «Автомобільний транспорт», «Транспортні технології». 
Комплексна мета навчання іноземної мови у ВСП РАТФК НУВГП спрямована на виховання, освіту і розвиток здобувачів ступеня вищої освіти «бакалавр» засобами навчальних дисциплін «Англійська мова», «Англійська мова за професійним спрямуванням», «Англійська мова (спецкурс)» і пов'язана насамперед 3 спрямуванням навчальної діяльності на вироблення у студентів необхідних іншомовних компетенцій, що у майбутньому дадуть можливість випускникам закладу освіти комфортно і професійно почуватися у сучасному світовому мультинаціональному просторі. Вона конкретизується такими чинниками:

виховання свідомого ставлення до обраної професії, потреби в практичному використанні іноземної мови в майбутній професійній діяльності;

розширення загальнокультурного світогляду студентів, їх ерудиції в різних галузях знань, зокрема й професійно значущих;

підготовка здобувачів вищої освіти до участі в міжкультурному спілкуванні в усній i писемній формах 3 урахуванням їх інтересів та професійних устремлінь;

розвиток у студентів таких важливих в професійному аспекті пізнавальних процесів, як довільна увага, логічна пам'ять, аналітичне мислення, мовна i мовленнєва культура, комунікативна компетенція.

У сучасній методиці викладання іноземних мов комунікативна компетентність розглядається як здатність інтерпретувати i здійснювати висловлювання відповідно до ситуації комунікації і соціокультурних правил суспільства. Вона передбачає уміння співрозмовників співвідносити мовленнєве висловлювання з цілями і ситуацією спілкування, розуміння взаємостосунків між тими, хто спілкується, а також уміння правильно організувати мовленнєве спілкування 3 урахуванням культурних і соціальних норм комунікативної поведінки (Ціпан, 2005 b).

Наприклад, під час вивчення теми «Влаштування на роботу» (в рамках навчальної програми спецкурсу «Англійська мова за професійним спрямуванням»), студентам була запропонована мовленнєва ситуація, що передбачала створення діалогу і засвоєння структури спеціальних та загальних запитань у Present i Past Simple 3 використанням професійної лексики. Мовленнсва ситуація: «You want to get a job in a trucking company. The company manager has invited you for an interview. Make up a dialogue using the given words and phrases». Наводимо приклад діалогу:

Interviewer: Let me introduce myself. I am the manager of our automobile company and we have an open position, so we have been interviewing applicants to fill the position as quickly as possible.

Candidate: Yes sir, I read about the position on your website, and I think I am a good fit.

Interviewer: Have you got any experience?

Candidate: No. I finished my studies and graduated last week. Now, I want to get a job in your company.

Interviewer: We need someone with qualification. What qualification have you got?

Candidate: I've got a bachelor degree.

Interviewer: What are you looking for in a job?

Candidate: The job should definitely help me grow in my career. I will be happy to learn and grow as I work in a passionate company like yours. Interviewer: You are 
right. There is plenty of room for advancement in our company. What are your strengths? Why should I hire you?

Candidate: I am a diligent person and a fast learner. I am very eager to learn. My friends also find me very easy to work with.

Interviewer: We'd like to offer you a job

Candidate: Thank you. When can I start?

Ефективними також є такі комунікативні завдання: проаналізувати посадову інструкцію автомеханіка автомобільної компанії та визначити основні компетенції, необхідні для успішного виконання роботи автомеханіка: What knowledge, skills and abilities does the position require? Pick out 3-5 areas of focus. Під час виконання завдання студенти виокремили такі професійні компетенції: teamwork, problem-solving, customer service, communication, negotiation, leadership, initiative, adaptability, time management.

Важливого значення у формуванні англомовної комунікативної компетенції ми надаємо інтернет-ресурсам, (у коледжі створені технічні можливості для їх використання в освітньо-виховному процесі), які забезпечують формування іншомовної комунікативної компетенції шляхом розвитку міжособистісних i інтерактивних мовленнєвих умінь. Інформаційні ресурси міжнародного сайту «Truck \& Trailer News» (http:// truckandtrailernews.com/add-a-contribution-to-yourenvironment) ми використали для обговорення статті «Екологічно безпечні автомобілі: транспорт майбутнього». Студентам було запропоновано скласти коротке висловлювання на означену тему, використавши професійноорієнтовану лексику: combustion of fuels - витрата палива; emit harmful gases викид шкідливих газів; gasoline engine - бензиновий двигун; save fuel - зберігати паливо; air pollution - забруднення повітря; fuel efficiency - ефективна витрата палива. Робота в режимі онлайн 3 посиланням на сайт (http://ecomotorcompany.blogspot.com/search/label/Eco-car) передбачає читання статті, висловлювання в режимі студент - студент на тему «Buying eco-friendly cars - For \& Against» (для студентів з середнім рівнем володіння англійською мовою); «The future transport - eco-friendly cars» (для студентів з високим рівнем володіння англійською мовою). Викладач надає допомогу під час роботи 3 інтернет-ресурсами.

У процесі роботи, спрямованої на пошук необхідної інформації, студенти оволодівають навичками читання автентичної літератури, збагачуючи при цьому свій словниковий запас, вдосконалюючи навички писемного мовлення англійською мовою, виконуючи післятекстові завдання. До прикладу, написати есе за матеріалами прочитаного, підготувати повідомлення, коментарі, висловлюючи власну точку зору (згоду чи незгоду) в режимі онлайн. При цьому практикується використання таких комунікативних прийомів: «Снігова куля», «Складання розповіді за ланцюжком», дискусійні ігри, драматизація, рольові ігри, завдання на пошук помилок, робота з партнером.

Використання Інтернет-ресурсів під час навчання англійської мови дозволяє відтворити реальну модель автентичного спілкування із носіями мови на актуальні теми в режимі online. Практичне оволодіння іноземною мовою здійснюється в процесі вирішення поставлених викладачем завдань, коли студенти навчаються розуміти зміст та вираження основного змісту прочитаного i почутого, при цьому створюючи свої оригінальні висловлювання, а не застосовують завчену напам'ять фразу. Водночас засвоєння певної граматичної 
структури, професійної лексики відбувається опосередковано як необхідний засіб для розуміння прочитаного.

Розвиток комунікативних компетенцій у студентів коледжу відбувається і на позааудиторних заняттях. Позааудиторна діяльність спрямована на розвиток інтересу до вивчення англійської мови та удосконалення умінь і навичок професійного мовлення відповідно до рівня В1. Позааудиторна діяльність 3 англійської мови передбачає роботу гуртка «Think English», структуру якого складають 4 творчі підгрупи: «Професійна англійська», «Країнознавство», «Театральне мистецтво», «Прес-центр».

Позааудиторна робота творчої підгрупи «Професійна англійська» має на меті розвиток інтересу до професії, розширення словникового запасу студентів шляхом опрацювання матеріалу 3 англомовних сайтів, читання автентичної літератури, обговорення виробничих ситуацій. Практикуються такі ефективні форми роботи зі студентами, як ділова гра «Моя майбутня професія організатор міжнародних вантажних перевезень», презентація «Транспорт майбутнього».

Студенти, які працюють в творчій підгрупі «Країнознавство», глибше ознайомлюються 3 історією та культурою Великої Британії, іiї звичаями та традиціями, розвиваючи при цьому комунікативні навички усного та писемного мовлення, формуючи навички толерантного ставлення до інших народів. Прикладом цього може слугувати дискусійне заняття «We are all unique», історичний портрет «British Queen Elizabeth II».

Розвиток комунікативних навичок іншомовного спілкування із студентами творчої підгрупи «Акторський гурт» відбувається під час підготовки та в процесі театральних вистав, «То be or not to be», «То Taras Shevchenko's 200-th birthday anniversary devoted», а також інсценівок, які відображаються національні свята англомовних країн, зокрема, «Helloween», «St.Valentine's Day», «Pancake Day» тощо.

Позааудиторна робота творчої підгрупи «Прес-центр» полягає у підготовці та випуску стіннівок на актуальні проблеми студентського життя, наприклад, «October 28 - Day of road transport workers», «Our future profession», інформаційних «блискавок» про події в групі, на курсі, в коледжі, зокрема, «Topical issue», «It's interesting to know», «Global warming, home carbon footprint and the ways to reduce it» тощо (Кощук, 2019).

До принципів організації позааудиторної роботи з англійської мови в межах комунікативного підходу належать:

мовленнєва спрямованість (навчання через спілкування);

функціональність (забезпечує комплексне вивчення мови 3 урахуванням іiі фонетичного, лексичного і граматичного аспектів);

ситуативність (рольова організація комунікаціі);

новизна мовленнєвих ситуацій (передбачає інформованість матеріалу, що використовується, новизну видів і форм організації занять, розмаїття прийомів роботи);

особистісна орієнтація спілкування 3 опорою на індивідуальне мовлення студента;

комплексна взаємодія як спосіб організації процесу, при якому студенти активно спілкуються один з одним.

Висновки і перспективи подальших розвідок. Організація викладання англійської мови у Відокремленому структурному підрозділі «Рівненський 
автотранспортний фаховий коледж Національного університету водного господарства та природокористування» спрямована на формування професійної компетентності у студентів і відбувається як під час навчального процесу, так і в позааудиторний час. При цьому увага акцентується на: навчання спілкування в різних видах мовленнєвої діяльності (читання, говоріння, слухання, письмо); функціональність у відборі навчального матеріалу; використання автентичних матеріалів і завдань, що сприяють формуванню комунікативних умінь і режимів роботи, які адекватні реальній комунікації (парна групова робота); індивідуалізація процесу навчання, використання особистісно-орієнтованого підходу.

\section{СПИСОК ВИКОРИСТАНИХ ДЖЕРЕЛ}

Методика викладання іноземних мов у середніх навчальних закладах. Підручник. Вид.2-е перероб./ кол.авторів під керівн.С.Ю.Ніколаєвої. К., Ленвіт. 2002. 328 c.

Лушина, Н. (2006). Професійна орієнтація як один 3 ефективних засобів підвищення ефективності навчання англійської мови. Іноземні мови в школі. № 8. C.31-35

Корж, Т. (2008). Навчання студентів вищих навчальних закладів анотування англійських професійно-орієнтованих тексті. Кандидат педагогічних наук. К. $14 \mathrm{c}$.

Ціпан, Т. (2005 а). А в мене була така ситуація! Способи інтенсифікації навчального процесу при вивченні англійської мови. Іноземні мови в навчальних закладах. №4. С. 46-49

Ціпан, Т. (2005 b). Розвиток комунікативних здібностей учнів при вивченні англійської мови [Development of students' communicative abilities in learning English]. Іноземні мови. №2. С. 51-56.

Кощук В. (2019). Позакласні заходи з англійської мови. Рівне: Рівненський автотранспортний коледж НУВГП. 40 с.

Truck \& Trailer News. URL: http:// truckandtrailernews.com/add-a-contributionto-your-environment [Дата останнього доступу 28.10.2020]

\section{REFERENCES}

Metodyka vykladannia inozemnykh mov u serednikh navchalnykh zakladakh. [Methods of teaching foreign languages in secondary schools]. Pidruchnyk. Vyd.2-e pererob./ kol.avtoriv pid kerivn.S.Iu.Nikolaievoi. K., Lenvit. 2002. 328 s. [in Ukrainian]

Lushyna, N. (2006). Profesiina oriientatsiia yak odyn z efektyvnykh zasobiv pidvyshchennia efektyvnosti navchannia anhliiskoi movy [Professional orientation as one of the effective means of improving the effectiveness of teaching English]. Inozemni movy $v$ shkoli. No 8. S.31-35. [in Ukrainian]

Korzh, T. (2008). Navchannia studentiv vyshchykh navchalnykh zakladiv anotuvannia anhliiskykh profesiino-oriientovanykh tekstiv [Teaching students of higher educational institutions annotation of English professionally-oriented texts]. Kandydat pedahohichnykh nauk. K. 14 s. [in Ukrainian]

Tsipan, T. (2005 a). A v mene bula taka sytuatsiia! Sposoby intensyfikatsii navchalnoho protsesu pry vyvchenni anhliiskoi movy [Ways to intensify the learning process in learning English]Inozemni movy v navchalnykh zakladakh. No4. S. 46-49. [in Ukrainian] 
Tsipan, T. (2005 b). Rozvytok komunikatyvnykh zdibnostei uchniv pry vyvchenni anhliiskoi movy. Inozemni movy. No 2. S. 51-56. [in Ukrainian]

Koshchuk V. (2019). Pozaklasni zakhody z anhliiskoi movy [Extracurricular activities in English]. Rivne: Rivnenskyi avtotransportnyi koledzh NUVHP. 40 s. [in Ukrainian]

Truck \& Trailer News. URL: http:// truckandtrailernews.com/add-a-contributionto-your-environment [Data ostannoho zvernennia 28.10.2020] [in English]

\section{FORMATION STUDENTS' LANGUAGE PROFESSIONAL COMMUNICATIVE COMPETENCE IN THE AUTOTRANSPORT PROFESSIONAL COLLEGE DURING LEARNING ENGLISH}

Victoriia Koshchuk

English teacher of the highest qualification category of

Separate structural unit "Rivne Autotransport

Professional College National

University of Water and Environmental Engineering”,

Rivne, Ukraine

ORCID: 0000-0003-1689-7388

e-mail: viktoriabelka74@gmail.com

Abstract. The article deals with the practical aspect of implementation the problem to the formation students' language professional communicative competence during learning English in the Autotransport professional College (from the experience of the highest category English teacher Koschuk V.M.).

It was found that communicative competence is the ability to interpret and make statements in accordance with the situation of communication and socio-cultural rules of society. It involves the ability of interlocutors to correlate speech with the goals and situation of communication, understanding the relationship between those who communicate, as well as the ability to properly organize speech communication taking into account the personality-oriented approach. Examples of formation students' language professional communicative competence in the Autotransport professional College by means of academic disciplines "English", "Professional use of English", "English (special course)" are given, including: work with information resources of the international site "Truck \& Trailer News", development of dialogues based on situational communication as to the topic "Applying for a Job", use of communicative techniques: "Snowball", discussion games, dramatization, role-playing games, bug fixes, partner work, etc.

The content of extracurricular activities in English concerning the students' foreign language professional communicative competence formation was revealed. It includes the development of interest in learning English, improving skills and abilities of professional speech according to level B1. The principles of organization of extracurricular work in English within the communicative approach are highlighted: speech orientation, functionality, novelty of speech situations, personal orientation of communication based on individual speech of the students. The main directions of the English club "Think English", consisting of 4 creative subgroups: "Professional English", "History of Britain", “Actor Group", "Press Center” were characterized.

Key words: foreign language professional communicative competence, professional-communicative skills, oral and written speech skills, extracurricular work, club work.

Стаття надійшла до редакиії 01. 10. 2020 р. 